\title{
風波と地震時の地盤沈下による 涸沼広浦砂州の変形とその復元 DEFORMATION OF HIROURA BEACH IN LAKE HINUMA DUE TO WIND WAVES AND GROUND SUBSIDENCE ASSOCIATED WITH 2011 GREAT EARTHQUAKE AND RECOVERY
}

\author{
宇多高明 1 ・高橋伸一 2 ・中村和也 3 ・三波俊郎 $4 \cdot$ 宮原志帆 4 ・酒井和也 5 \\ Takaki UDA, Shin-ichi TAKAHASHI, Kazuya NAKAMURA, Toshiro SAN-NAMI, \\ Shiho MIYAHARA and Kazuya SAKAI \\ 1 一般財団法人士木研究センター常務理事なぎさ総合研究室長（†110-0016 東京都台東区台東 1-6-4） \\ 2 茨城県土木部河川課（干310-8555 茨城県水戸市笠原町 978-6） \\ 3 茨城県水戸土木事務所（干310-0802 茨城県水戸市柵町 1-3-1） \\ 4 海岸研究室（有）（干160-0011 東京都 新宿区若葉 1-22 ローヤル若葉 301） \\ 5 一般財団法人土木研究センター（干110-0016 東京都台東区台東 1-6-4）
}

\begin{abstract}
During the 2011 Great Earthquake, ground subsidence of $20 \mathrm{~cm}$ occurred in Lake Hinuma. Since then, lakeshore erosion became dominant on Hiroura Beach located in the eastern part of the lake, with pine trees grown along the shoreline being damaged and the root of the pine trees being exposed to waves. In this study, long-term lakeshore changes of the area were investigated using an old map produced in 1885 and aerial photographs taken since 1947 along with the site observation on February 24, 2012. Although Hiroura Beach was a cuspate foreland before land reclamation, the lakeshore has eroded by wind waves and a marked change was triggered by ground subsidence associated with the Great Earthquake. To recover sandy beach, the effect of beach nourishment was investigated using the contour-line-change model considering the changes in grain size of bed materials.
\end{abstract}

Key Words : Lake Hinuma, Hiroura Beach, 2011 Great Earthquake, ground subsidence, erosion, beach nourishment

\section{1. はじめに}

涸沼は，水戸の南9kmに位置し，涸沼川と那珂川を経 て太平洋と繋がる汽水湖であり，ヤマトシジミを始めと する貴重な種の生育場となっている．広浦砂州はこの湖 の北岸東部に伸びており，東向きに細長く伸びた尖角岬 であったが，砂州北側が干拓されたために現在では緩く 湾曲した堤防の南面に沿って細長い砂州として伸びてい る.この砂州は現在公園として利用されている. 広浦砂 州は，湖内へと細長く伸びた形状を有するがゆえに砂州 の両側に湖面を望むことができる風光明媚な場所であっ た.このことから, 水戸徳川家第九代藩主斉昭公が天保 四年（1833年）に領内を巡視した際，水戸八景の一つと して選ばれた。この砂州は，長い間ほぼ安定な姿を保っ
てきたが，2011年3月11日の東北地方太平洋沖地震によ る約 $20 \mathrm{~cm}$ の地盤沈下 ${ }^{1)} の$ 後, 侵食が顕在化するとともに, 汀線沿いに生育していた多くの松の根が波に曝され，枯 れ死する可能性が高まった，本研究では，広浦砂州の長 期間の変遷を調べるとともに，2012年2月24日には現地 踏査を行って侵食原因を考察した. 湖浜の長期的変化の 分析には宇多ら ${ }^{2)}$ による霞ヶ浦の蓮河原地区での分析と 同じ手法を用いた，その上で粒径を考慮した等深線変化 モデル33を用いて湖浜変形を再現し，海浜を復元するた めの養浜の効果について検討した.

\section{2. 広浦砂州の長期的変遷}

1885年作成の陸軍迅速測図より切り出した涸沼の地形 
図を図-1に示す．1885年には広浦砂州は東向きに伸びて いたが，戦後砂州の北側は干拓され，堤防南面に細長い 砂州が残された.

図-1 (b) に示寸矩形区域での湖岸線変化を図-2に示す. 1885年には，長洲の集落から大きく左に湾曲した細長い 尖角岬が伸びていた，当時既に長洲から約 $400 \mathrm{~m}$ （現在 の石碑付近）までの砂州上には家屋が建てられていた。 1948年では，細長い尖角岬の北側に幅約 $20 \mathrm{~m} の$ 三日月状 の水域を残して干拓堤防が伸ばされた。 三日月状の水域 の東端の地点Cには小さな湖口が開いていたが，これは 干拓地からの排水がこの三日月状の水域を通して行われ ていたためと推定される. 現在の広浦砂州から見ると, 砂州の北面に沿って干拓堤防が伸ばされたように見える が，実際には，1948年の空中写真に示すように，三日月 状の水域を残して干拓堤防が伸ばされた。 なお，1948年 の空中写真に示寸石碑は，その後次第に規模が拡大され た水戸八景の碑である.

1961年には，砂州と堤防の間にあった水域には排水路 からの土砂が堆積するとともに，水域の大部分が植生で 覆われた. しかし砂州南面では大きな変化は生じていな かった。 また，C点には旧河口があったために汀線が局 所的に窪んでいた．1975年では，広浦の西側，長洲の集 落の西側に広浦漁港が造られた．同時に広浦漁港の東側 には突堤 $\mathrm{a}, \mathrm{b}, \mathrm{c}$ が伸ばされ，突堤 $\mathrm{a} の$ 西側では汀線が前進 した. これと対照的に, 突堤 $\mathrm{c} の$ 東側の鳥居付近では汀 線が後退傾向となった. このような汀線変化状況より， 長洲付近では東向きの沿岸漂砂が卓越していることが分 かる．また広浦砂州の北側にあった三日月状の水域を経 た排水に代わって，干拓地の排水のための排水路が砂州 を斜めに横断して開削された. このため地点Cに1961年 まであった開口部は完全に閉ざされた。 また砂州背後の 三日月形の水域はヨシで覆われた低地に変わった. その 後, 1992年には排水路の東側の浜幅がやや狭まり，2005 年では大きな変化はなかったが，東日本大震災後の2012 年には2005年と比べて汀線が後退した.

図-3は1948年基準での2012年までの汀線変化を示寸. 突堤a, b, cでは，2005年までに突堤西側で三角形状の汀 線前進が起きた一方, 調査地域の西端にある鳥居から排 水路までの間の汀線は鳥居の東側直近でやや大きな後退

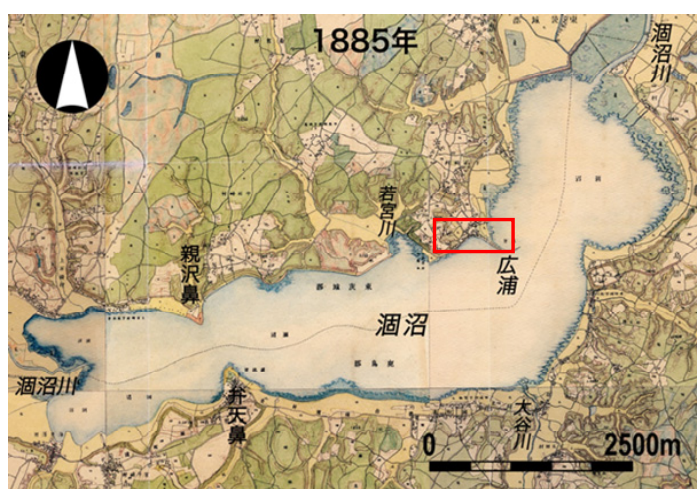

図-1＼cjkstart涸沼全域の迅速測図（1885年） (a) 1885 年 (迅速測図)

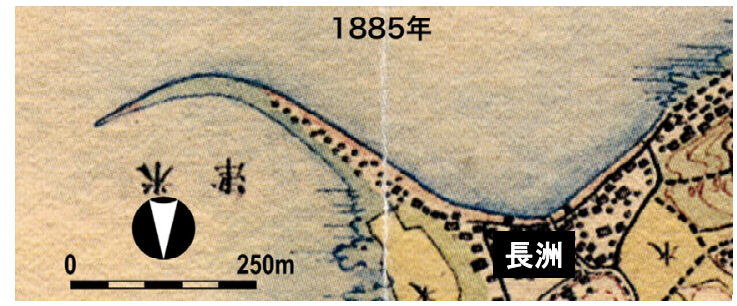

(b) 1948 年

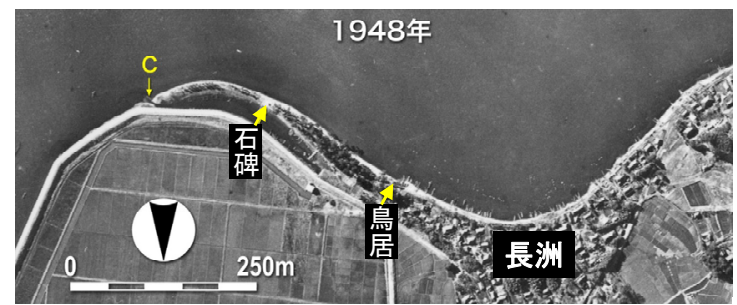

(c) 1961 年

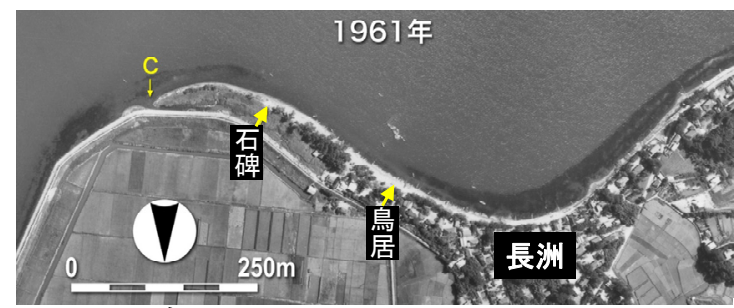

(d) 1975 年

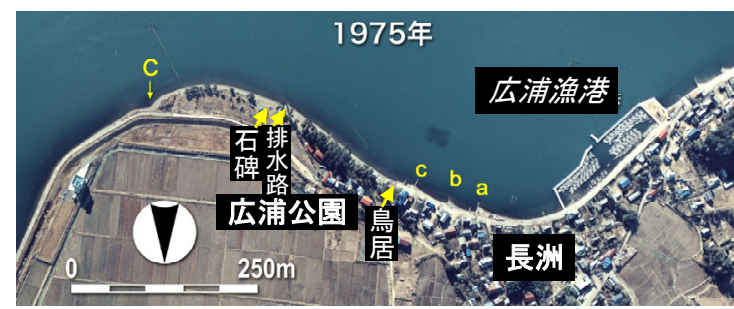

(e) 1992 年

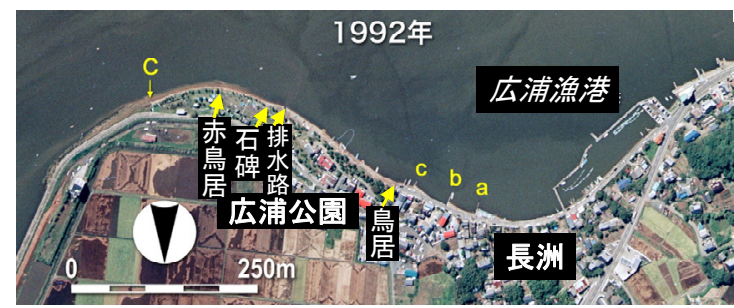

(f) 2005 年

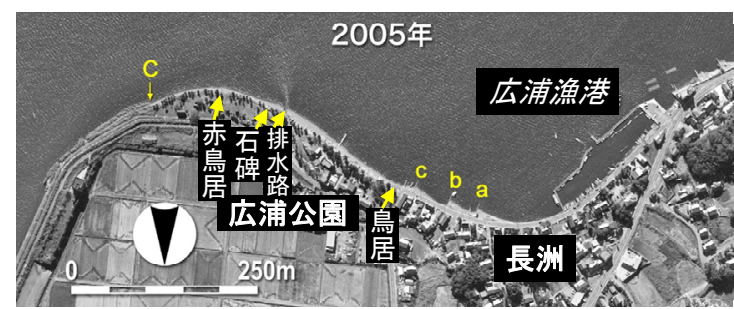

(g) 2012 年

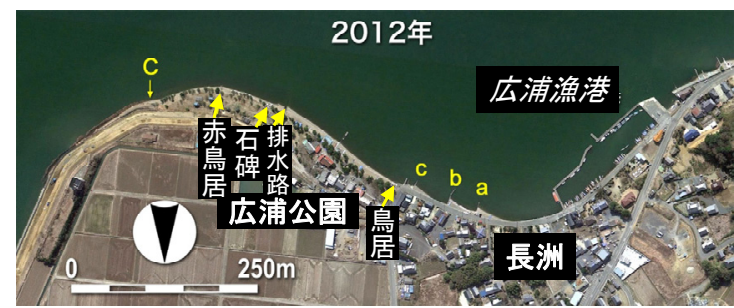

図-2＼cjkstart広浦周辺の迅速測図、空中写真および衛星画像 


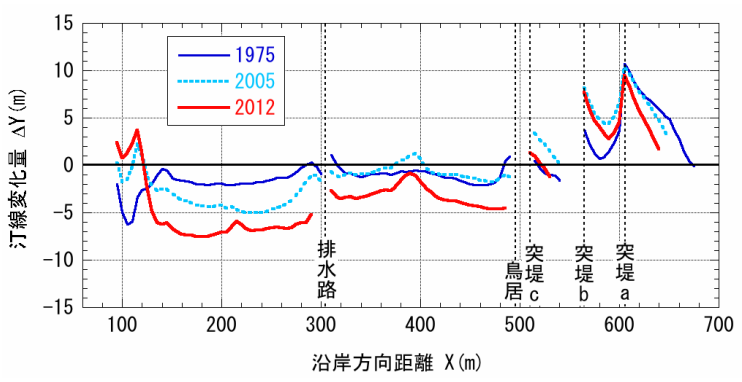

図-3 1948年基準の汀線変化

量を示してはいたがほぼ安定であった。しかし排水路の 東側では汀線後退量が大きく, 最大 $5 \mathrm{~m}$ 程度の汀線後退 が見られた．また，地震後の2012年では，2005年と比較 して汀線が全体的に $2 \sim 3 \mathrm{~m}$ 後退した。当地近傍における 地震時の垂直変動量は約 $0.2 \mathrm{~m}$ であり，前浜勾配を $1 / 10$ と すると約 $2 \mathrm{~m} の$ 汀線後退量に相当するが，この結果は図一 3から読み取れる值と整合的である。

\section{3. 広浦砂州の侵食実態}

2012年の衛星画像（図-2(g)）に示したように，広浦 砂州は排水路から東側に緩く湾曲している。 この区域の 踏査は2012年2月24日に実施した。まず踏査区域の西端 にある排水路を東向きに望んだのが写真-1である．排水 路は不透過構造のため東向きの沿岸漂砂が阻止され，排 水路の西側直近で汀線が前進していた．この排水路の東 隣には石積み護岸で囲まれた水戸八景の碑がある（写真 -2）。護岸の手前付近は侵食の結果，粒径の大きな砶や コンクリート片のみが散乱していた。水戸八景の碑の東 側隣接部では，写真-3のように汀線近傍に生育し，湖浜 景観の一部を構成していた松付近が侵食されたため土囊 が円形に積まれていた，写真-4は，砂州の東部に生育し
ていた松の根付近の侵食状況を示す．応急復旧として水

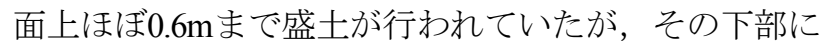
あった土囊が露出していた.

\section{4. 湖浜保全区域の選定と設定座標系}

ここでは地震前後の変形に着目し，2012年の空中写真 （図-4）を参照すると，広浦公園の西側にある突堤 $\mathrm{a}, \mathrm{b}$, cでは，いずれも西側汀線が前進していることから，当 地区では東向きの沿岸漂砂が卓越していると見られる.

しかし，図-3によれば地震前には排水路西側の湖浜はほ ぼ安定状態にあったことから検討対象区域から外し，排 水路の東 $180 \mathrm{~m}$ にある点D点までの区域で保全策を検討し た.この区域の湖岸線は緩やかな凸状を呈しているので, 汀線位置の計測・解析にあたっては，図-4に示すように 湖岸線に沿って西向きに座標軸（X軸）を設定し，この 曲線座標に沿う距離を沿岸距離とし，各地点においてX 軸に対し直角沖向きに汀線変化量を測定した.

検証計算に必要とされる汀線は，1975, 2005, 2012年に 取得されたものの，地震直前の2011年汀線は測定されて

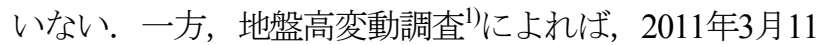
日の大地震により広浦周辺では約 $0.20 \mathrm{~m}$ の地盤沈下が生

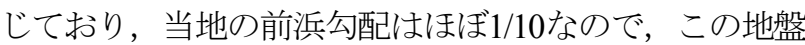
沈下量に海底勾配の逆数を乗ずると汀線後退量はほぼ $2 \mathrm{~m}$ となった。 そこで地盤沈下後の2012年の実測汀線が $2 \mathrm{~m}$ 沖にあったと仮定して2011年の地震前の汀線を推定 した. 次に，2011年の推定汀線を基準として各年の汀線 変化量を算出した上で，2011年の推定汀線を直線に引き 伸ばした展開座標上における汀線変化量として表示した。 ここに，展開座標とは，宇多ら ${ }^{4)}$ が涸沼親沢鼻を対象と した湖浜変形計算で用いたもので，曲線状の汀線に沿つ て沿岸方向距離を直線に引き伸ばした座標であり，汀線

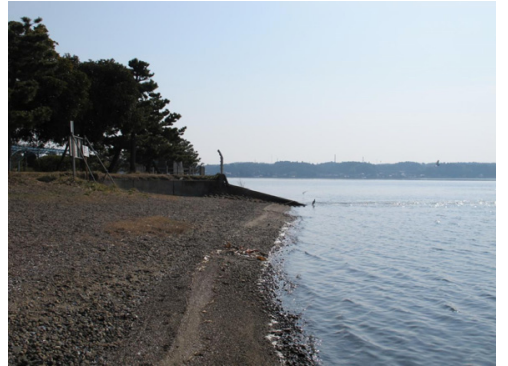

写真-1 踏査区域西端にある排水 路を東向きに望む

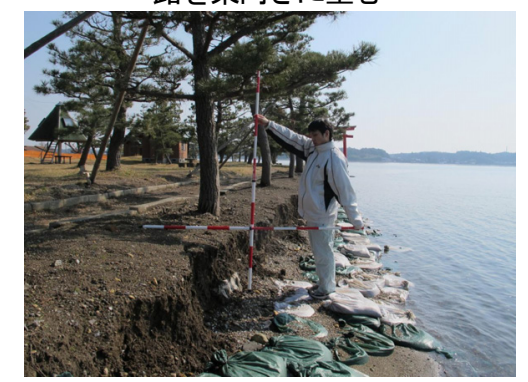

写真-4 応急復旧としての0. 6m厚の盛土の流出

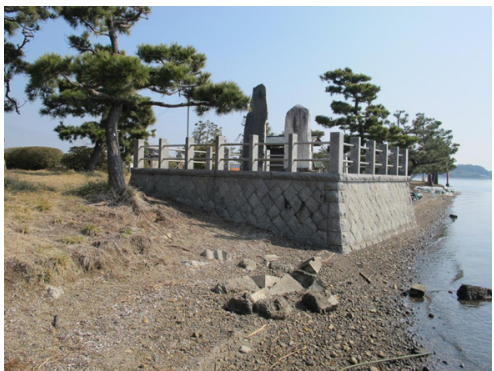

写真-2 石積み護岸で囲まれた水戸 八景の碑

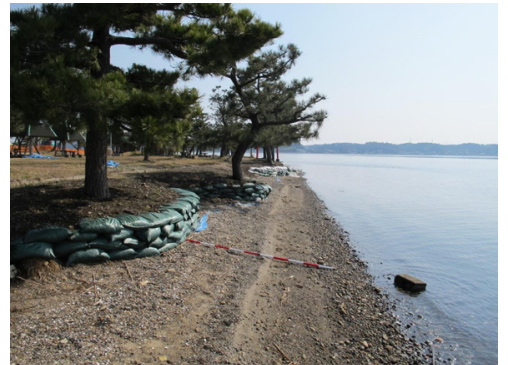

写真-3 水戸八景の碑の東側隣接部での松 付近の侵食と土囊による応急復旧

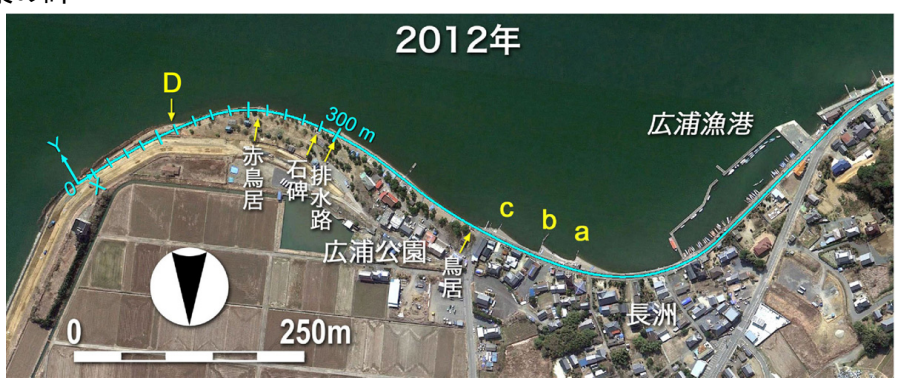

図-4２012年の空中写真上に定めた座標系 
変化量はこの座標軸と直角方向の変位として示される. 上記展開座標系では，D点と排水路の位置はそれぞれ $\mathrm{X}=120 \mathrm{~m}, 300 \mathrm{~m}$ で与えられる.

2011年の推定汀線に沿って設定した展開座標系に基づ いて各年の汀線変化量を読み取り, 各時期の汀線変化量 を1975年基準での汀線変化量に変換し，その上で1975年 を初期值とした2012年までの汀線変化量を算出した結果 を図-5に示す．図-5によれば，排水路西側区域では地震 前の2011年までの汀線変化はわずかであり汀線は安定し ていた。一方，排水路東側では2011年前までにX=125〜 $280 \mathrm{~m}$ の区域で全体的に汀線が後退する一方，X=95〜 125mではヨシ帯により東向きの沿岸漂砂が阻止された 結果，局所的に汀線が前進していた．排水路の東側では 2005年，2011年と時間経過とともに汀線後退量が増加し ていたが，2012年には地盤沈下に伴って汀線が平行移動 しつつ後退した.このような汀線変化状況と現地の侵食 状況より，侵食対策の必要区間は排水路より東側区域に 絞ることができる．なお，図-5において1975年基準で見 るとD点付近で汀線が大きく突出しているが，これは汀 線が沖向きに突出したのではなく，その付近が旧水路の 出口であったことにより元々汀線が四状となっており， そこに砂が堆積して汀線が滑らかな形状になったためこ のような汀線変化が現れたものである.

広浦砂州の構成材料については，2012年2月24日に排 水路西側近傍の汀線付近で調查を行った結果, 図-6が得 られている. 湖浜材料は中礫（4.75 19mm） から中砂 $(0.25 \sim 0.85 \mathrm{~mm})$ まで幅広い分布を有し, 中央粒径は $1.69 \mathrm{~mm}$, 含有率が最も高いのは粗砂（0.85〜2.0mm）の 41.9\%であった.

\section{5. 再現計算の条件}

湖浜変形予測計算には，粒径を考慮した等深線変化モ デル゙タ用いた．計算は，現況再現計算（ケース1）と予 測計算（ケース2,3）からなる. ケース1では，1975〜 2012年の汀線変化の再現を行い，これにより計算モデル の妥当性を確認した. 予測計算は, 養浜の夕行うケース 2 と, 突堤十養浜のケース3からなる. 計算において, 涸 沼の平均水面はM.S.L.=T.P.+0.3mにあるので，湖浜高は この平均水面を基準とした高さとして表示した．湖浜縦 断形は，深浅測量データを基に図-7に示すように定め, バーム高 $\mathrm{h}_{\mathrm{R}}$ を $0.5 \mathrm{~m}$ (T.P.+0.8m), 波による地形変化の限界 水深 $\mathrm{h}_{\mathrm{c}}$ を $-1.8 \mathrm{~m}(\mathrm{~T}$.P. $-1.5 \mathrm{~m})$ とした. 湖浜勾配は $\mathrm{Z}=0.5 \sim 0 \mathrm{~m}$ では $1 / 10, \quad Z=0 \sim-1.8 \mathrm{~m}$ では $1 / 15, \quad Z=-1.8 \sim-2.3 \mathrm{~m}$ では $1 / 50$ とし， $\mathrm{Z}=-1.8 \mathrm{~m}$ 以深（ $\mathrm{h}_{\mathrm{c}}$ 以深） は波作用による侵食は生 じないものとして，固定床として扱った.

縦断形は図-7のように汀線で勾配が変化し，前浜での $1 / 10$ 勾配が水面下では $1 / 15$ と緩くなる. このことは水面 上と水面下で粒径が異なることを示しているが，これに

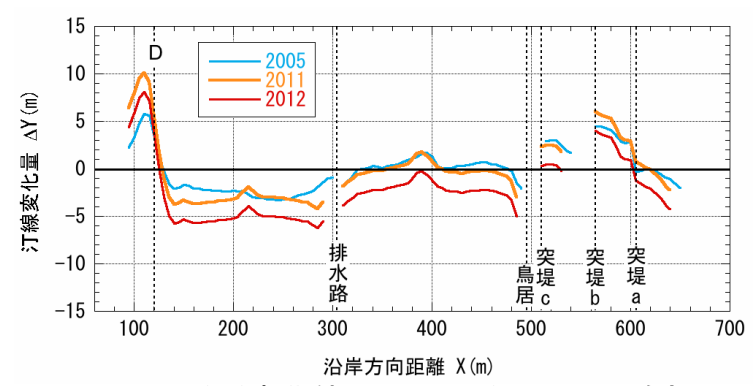

図-5 1975年を初期値とした2012年までの汀線変化量

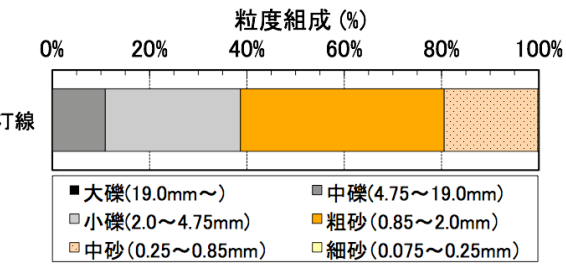

図-6 排水路西側近傍の汀線付近での底質調査結果

対応する実測データがない. そこで粒径数を2と仮定し， 粒径ごとの平衡勾配を水深帯により変えた. 図-6によれ ば，前浜底質は中砂〜中磎の広い粒径バンドで構成され ているものの礫を多く含む粗粒土砂が堆積しており, 礫 の含有率が $38 \%$, 残りの $42 \%$ が粗砂であって, 中央粒径 も1.69mmと大きい. このことから, 前浜構成土砂の代 表粒径は $\mathrm{d}_{2}=2 \mathrm{~mm}$, 平衡勾配 $\tan \beta_{\mathrm{c}}=1 / 10$ の砂が堆積してい ると仮定した. 一方, 湖面下では勾配が $1 / 15$ と緩いこと から，相対的に粒径が小さい代表粒径 $\mathrm{d}_{1}=1.5 \mathrm{~mm}$ の砂が, 平衡勾配 $\tan \beta_{\mathrm{c}}=1 / 15$ を保って堆積していると仮定した.

現況再現計算は，前述の2011年推定汀線上に設けた展 開座標)を用いるものとし, 初期地形はこの展開座標上 において1975年汀線位置を定めた上，図-7に示寸縦断形 を汀線が一致するよう岸沖方向にずらすことにより断面 形を定めた. 入射波高はバーム高と同等の波高として $0.5 \mathrm{~m}$ とた．波向に関しては，広浦では西側からの入射 波浪が卓越するものの, 東側からの入射もあり, それら の作用が重合した結果として現況の砂州形状が定まって いると考えられる.

1948年基準での汀線変化(図-3)によれば，排水路西側 の汀線は地盤沈下の影響を除けばほぼ安定していた。し たがって排水路位置での卓越波の入射角はほぼ 0 と見な すことができる. 一方，排水路東側の $\mathrm{X}=280 \sim 125 \mathrm{~m}$ 間で は2005年までに中央部で最大 $5 \mathrm{~m}$ の汀線後退が起きてい る. 排水路東側で侵食のみが起きている状況より，この 汀線変化は, 排水路により西側区域からの沿岸漂砂が阻 止される一方，東向きの沿岸漂砂により対象区域から土 砂が運び去られたため生じたと考えることができる，こ のことから，排水路地点では波向角を 0 と仮定できるが， 図-4によれば，湖岸線は広浦の東部では反時計回りに回 転している. よって排水路からD点へ向かって次第に入 射角が大きくなる分布となると推定できる. ただし既往 の空中写真判読では入射角に関する情報が得られないこ とから, trial and errorの手法により東端のD点での入射角 


\section{表-1＼cjkstart計算条件}

\begin{tabular}{|c|c|}
\hline 計算手法 & 粒径を考慮した等深線変化モデル（熊田ら，2007） \\
\hline 計算区域 & 排水路〜東部のヨシ帯 \\
\hline 入射波条件 & 砕波波高 $\mathrm{H}_{\mathrm{b}}=0.5 \mathrm{~m}$, 砕波角 $\alpha_{w}$ : 図-8 参照 \\
\hline 予測期間 & 10 年 \\
\hline $\begin{array}{l}\text { 代表粒径（2 粒径）と } \\
\text { 平衡勾配 }\end{array}$ & $\begin{array}{l}\text { 粒径 } \mathrm{d}_{1}=1.5 \mathrm{~mm}, \text { 平衡勾配 } \tan \beta_{\mathrm{c} 1}=1 / 15 \\
\text { 粒径 } \mathrm{d}_{2}=2.0 \mathrm{~mm} \text {, 平衡勾配 } \tan \beta_{\mathrm{c} 2}=1 / 10\end{array}$ \\
\hline 初期地形 & $\begin{array}{l}2011 \text { 年汀線を展開座標でモデル化した直線平行等深線（陸上 } \\
1 / 10,0 \text { - } 1.8 \mathrm{~m} 1 / 15,-1.8 \mathrm{~m} \text { 以深 } 1 / 50) \\
\text { 水深・標高の基準は M. S. L. = T.P. }+0.3 \mathrm{~m}\end{array}$ \\
\hline 初期粒径含有率 & $\begin{array}{lll}\mathrm{z}=+0.5 \sim 0 \mathrm{~m} & \mu_{1}: \mu_{2}=0: 1 \\
\mathrm{z}=0 \sim-1.8 \mathrm{~m} & \left.\mu_{1}: \mu_{2}=1: 0 \quad \text { (海底勾配 } \tan \beta=1 / 10\right) \\
\text { 底勾配 } \tan \beta=1 / 15)\end{array}$ \\
\hline 漂砂量係数 & $\begin{array}{l}\text { 沿岸漂砂量係数の } \mathrm{A}=3 \times 10^{-3} \\
\text { 岸沖沿岸漂砂量比 } \gamma=0.1\end{array}$ \\
\hline 沿岸・岸沖漂砂の水深分布 & 宇多・河野（1996）の3 次式 \\
\hline 限界水深・バーム高 & 波による地形変化の限界水深 $\mathrm{h}_{\mathrm{c}}=1.8 \mathrm{~m}, \quad$ バーム高 $\mathrm{h}_{\mathrm{R}}=0.5 \mathrm{~m}$ \\
\hline 土砂落ち込みの限界勾配 & 陸上 : $1 / 2$, 水中 : $1 / 3$ \\
\hline 計算等深線範囲 & $\mathrm{z}=+0.5 \sim-2.3 \mathrm{~m}$ \\
\hline 計算メッシュ & 沿岸方向 $\Delta X=5 \mathrm{~m}$, 鉛直方向 $\Delta Z=0.1 \mathrm{~m}$ \\
\hline 境界条件 & 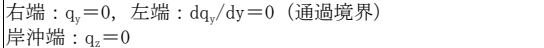 \\
\hline
\end{tabular}

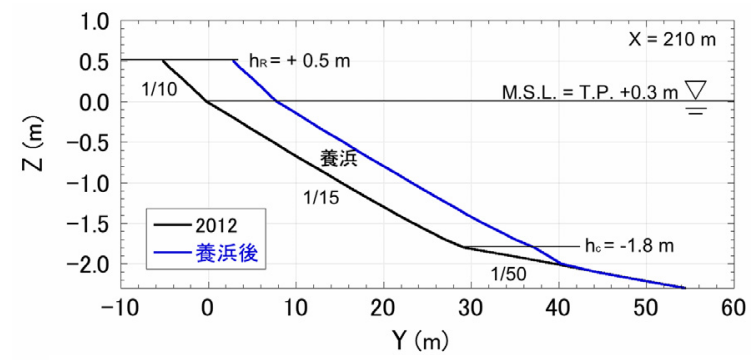

図-7 深浅測量データを基に定めた湖浜縱断形

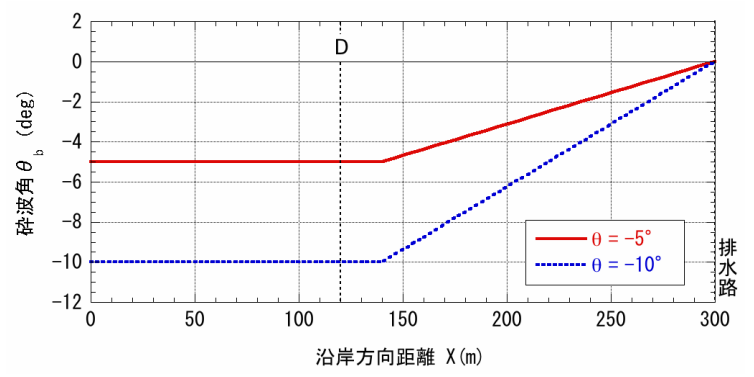

図-8 波向の沿岸方向変化

を設定し，排水路〜D点では線形的に波向が変化すると して計算を行い，実測汀線と適合寸る波向条件を選定し た．具体的には，D点での入射角を $10^{\circ}$ と $5^{\circ}$ と仮定し て計算を行った。図-8には設定した波向分布を示寸.

図-4によれば，1975年にはD点は砂浜と護岸との接点 に位置していたが，2012年までには西部から運び込れれ た土砂が堆積してD点付近では汀線が前進している。こ のことからD点 $(\mathrm{X}=120 \mathrm{~m})$ の東側には仮想領域（ヨシ 帯）を設定した。このヨシ帯は，ある程度の沿岸漂砂の 阻止効果を有すると考えられるので，X=120mより東側 にあるヨシ帯の沿岸漂砂阻止効果は小突堤により考慮す ることとし，小突堤の設置位置はX=115m，先端は2011 年の推定汀線位置とした。 さらに，排水路の東側隣接部 には護岸が設置されているので，X=290〜300m区域の 2011年汀線位置には護岸を設置した。この護岸の西側に は排水路の壁体があることから，そこには沿岸漂砂を阻 止する壁を設置し，沿岸漂砂量を0とした。

予測計算に用いた初期地形は2012年の再現計算の結果 とし，再現計算で得られた地形で養浜を行った．予測計 算の結果は，2012年の現況汀線基準のほうが理解しやす いことから，現況再現計算で用いた2011年汀線の展開座 (a) 1975 年

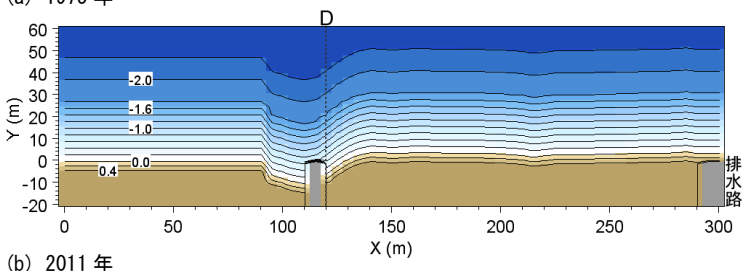

(b) 2011 年
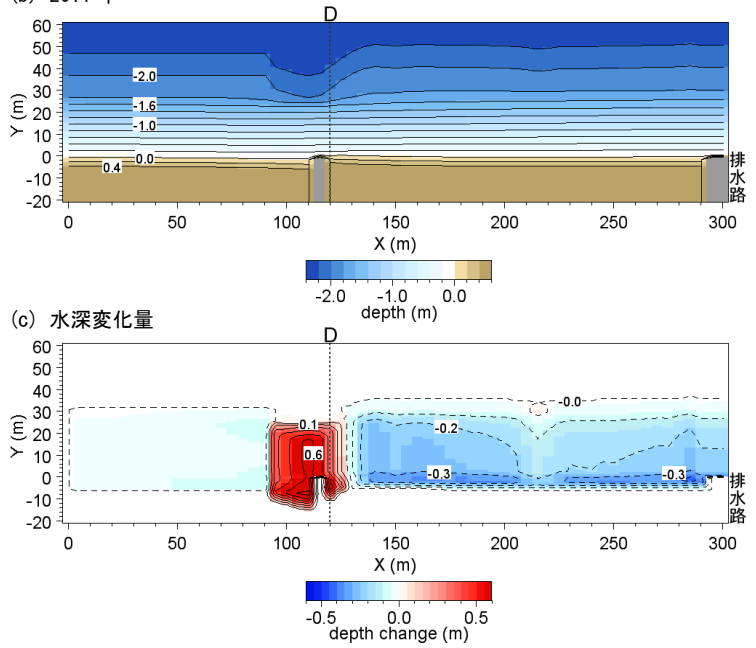

図-9 1975 2011年の地形変化の再現計算結果

（a） 2011 年汀線基準

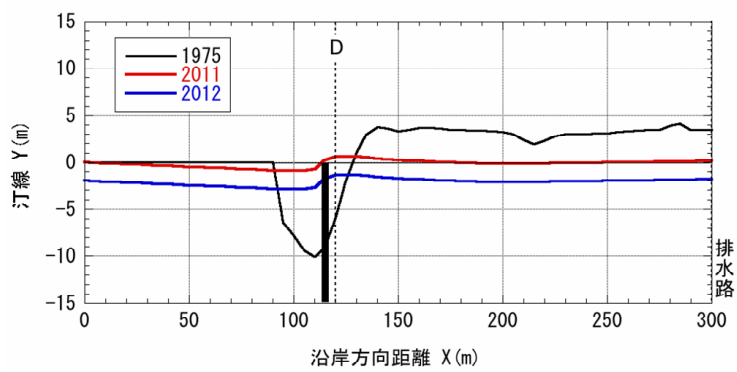

(b) 2011 年

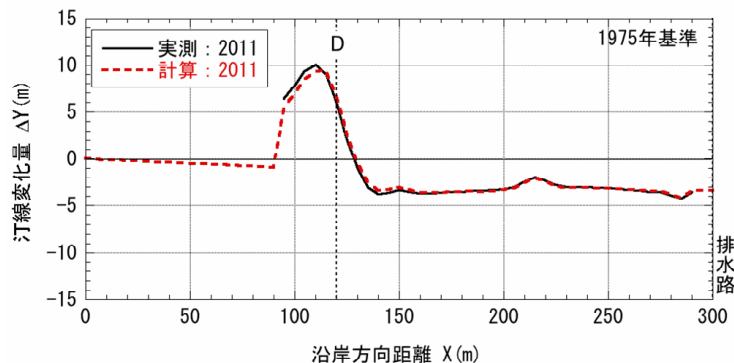

(c) 2012 年

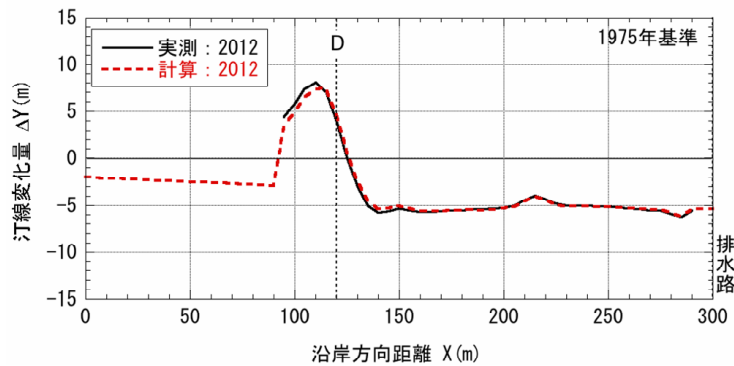

図-10１975～2011年の汀線変化の比較

標を $2 \mathrm{~m}$ 岸側にずらすことにより，2012年の再現計算で 求められた汀線上に設定した座標を用いて計算を行った。 養浜は，X=120〜290mの区域で行うこととし，図-3に示 した1948年基準で見た2012年までの汀線後退量が最大 
$8 \mathrm{~m}$ 程度であることから養浜幅は $8 \mathrm{~m}$ とした．養浜は，排 水路からD点までの間で行うこととし，水深方向には高 さ0.5mから-1.8mまでの間で, $20.2 \mathrm{~m} / \mathrm{m}$ の土砂を投入す る案を設定した. 土砂総量は $3638 \mathrm{~m}^{3}$ である. さらにヨシ 帯の漂砂阻止効果を表わ寸小突堤は現況再現計算と同様 $\mathrm{X}=115 \mathrm{~m}$ に設置した。 また，排水路左岸の護岸（X=290 ～300m）の護岸位置も同様に2012年汀線 $+2 \mathrm{~m}$ 沖とした.

\section{6. 再現計算と予測計算の結果}

\section{(1) 再現計算}

D点での波向角は-5 $5^{\circ}$ と-10 と設定したが，実測值と の対応は-5 5 の場合であった。 そこで以下では-5 合の計算結果を示す（図-9）。1975年と, 求められた 2011年地形，および初期地形からの水深変化量を示寸.

D点での入射角が右斜めに $5^{\circ}$ と排水路へと波向角が小 さくなる波向分布のため，D点から排水路間が侵食され， $\mathrm{D}$ 点付近にあった窪みのう $\mathrm{h}_{\mathrm{c}}=1.8 \mathrm{~m}$ 以浅に集中的に堆積 するという結果となった. 図-10は2011年汀線を基準と した汀線変化，および1975年基準での2011,2012年まで の汀線変化を示す．D点の西側の汀線がほぼ平行に後退 する一方，1975年当時局所的に嵀んでいた部分で堆砂が 起きて汀線が前進するという変化が起きた. 1975年基準 での2011，2012年の汀線変化でも実測と予測汀線はほぼ 一致している.

\section{（2）予測計算の結果}

図-11は，D点から排水路までの $180 \mathrm{~m}$ 間で等深線を $8 \mathrm{~m}$ 平行移動する形で養浜した場合の 10 年後の予測地形と地 形変化量を示す. D点付近では等深線形状に段差が付く ため，東向きの沿岸漂砂が発生し，D点から排水路間の 堆積土砂が東側へと流れ出る. 流出した土砂は現況のヨ シ帯付近に堆積することになる. しかしながら5年後ま での土砂流出量は $350 \mathrm{~m}^{3}, 10$ 年後でも $576 \mathrm{~m}^{3}$ と小さく, 総養浜土砂量 $3638 \mathrm{~m}^{3}$ に対する割合は5年後で9.6\%，10年 後で16\%であった. このように養浜を行ったのみでは, 東向きの沿岸漂砂により養浜砂の流出が起こるものの, その土砂流出量は大きくなかった. よってまずは養浜を 行い, 状況を監視しつつ必要に応じて土砂を戻す順応的 管理での対応が可能と考えられた.

\section{7. まとめ}

最終的に，現在の広浦が有する優れた景観に配慮し， 養浜を主とする対策を提案した，具体的には，排水路か ら東側に180m離れたD点（ヨシ帯との境界）までの間に おいて, 総量 $3638 \mathrm{~m}^{3}$ の土砂を $20.2 \mathrm{~m}^{3} / \mathrm{m}$ の割合で投入寸れ ば，前浜幅を平均 $8 \mathrm{~m}$ 前進させることができ，1948年当
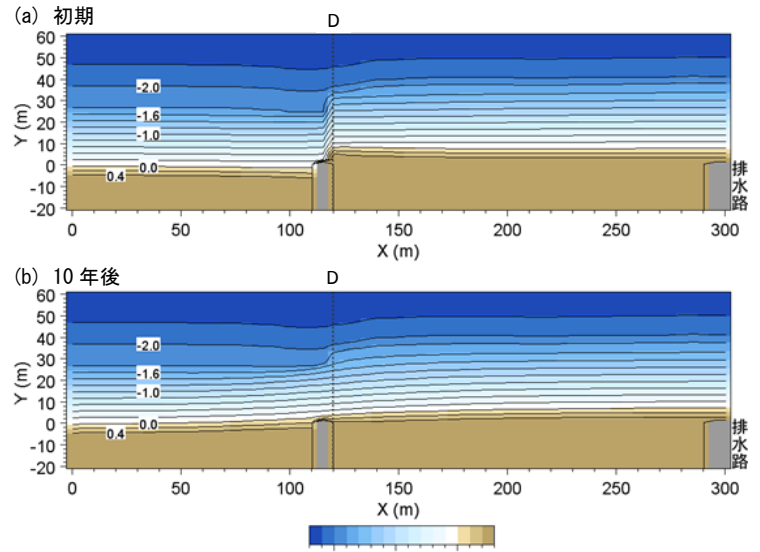

$-2.0 \operatorname{depth}^{-1.0}(\mathrm{~m})$

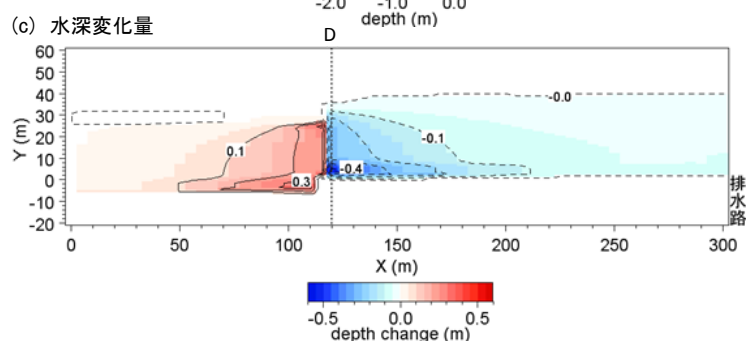

図-11 養浜から10年後の予測地形

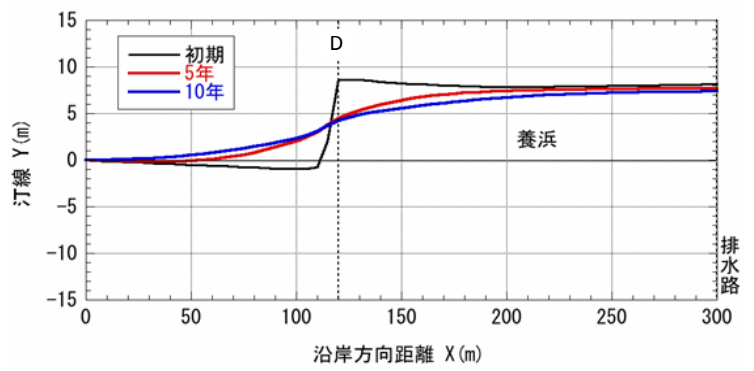

図-12 養浜から10年後の汀線変化

時の湖浜を復元させることが可能となった，その際，養 浜材料としては現地湖浜を構成する $\mathrm{d}_{2}=2 \mathrm{~mm}$ 程度で, 縦 断勾配が $1 / 10$ 程度となる粗粒材料を用いる必要なことが 明らかになった. 東端部に突堤を配置寸れば土砂の流出 量を減少させることが可能ではあったが，江戸時代から 続く砂州の景観への影響を考えれば今回構造物の選択は 避けるべきとの意見が強かったことから，突堤案につい ては省略した。

\section{参考文献}

1) 国土地理院 GPS 連続観測から得られた電子基準点の地款変 動: http://www.gsi.go.jp, 2011 （参照 2011 年 8 月 31 日）.

2) 宇多高明・三波俊郎・石川仁憲 : 霞ヶ浦における湖岸植生帯 の長期的変遷-蓮河原地区の例, 水工学論文集, 第53巻, pp.1363-1368, 2009.

3) 熊田貴之・宇多高明・芹沢真澄 : 卓越粒径集団に応じた平 衡勾配を考慮した等深線・粒径変化モデル，土木学会論文集 B, Vol.63, No.2, pp.154-167, 2007.

4) 宇多高明・住谷廸夫 - 矢澤 肇・大谷靖郎・厚坂祐次 : 展開 座標を用いた汀線変化モデルによる親沢鼻砂嘴の地形変化予 測, 海岸工学論文集, 第45巻, pp.541-545, 1998.

(2013. 9. 30受付) 